\title{
APPLICATION OF SRI LANKA ACCOUNTING STANDARDS AND OTHER REGULATORY REQUIREMENTS BY THE REGIONAL DEVELOPMENT BANKS
}

\author{
by
}

K H R CHANDIKA

M.Sc. in Management 


\section{APPLICATION OF SRI LANKA ACCOUNTING STANDARDS AND OTHER REGULATORY REQUIREMENTS BY THE REGIONAL DEVELOPMENT BANKS}

by

\section{K H R CHANDIKA}

GS/M.Sc./MGT/2945/06

Thesis submitted to the University of Sri Jayewardenepura for the award of the Degree of Master of Science in Management in 2013 
The work described in this thesis was carried out by me under the supervision of Prof. Samanthi Senarathne and a report on this has not been submitted in whole or in part to any university or any other institution for another Degree/Diploma.

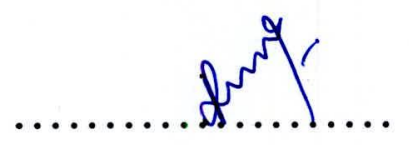

K H R Chandika 
I certify that the above statement made by the candidate is true and that this thesis is suitable for submission to the University for the purpose of evaluation.

\section{Slenaratue}

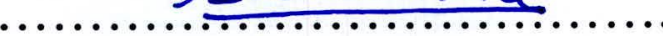

Prof. Samanthi Senarathne

Date

Supervisor 


\section{Contents}

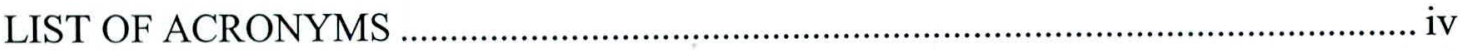

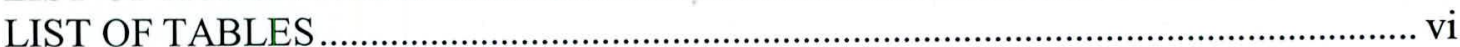

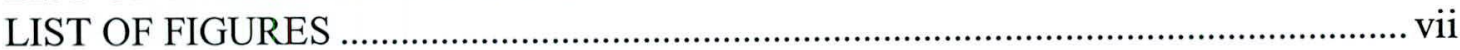

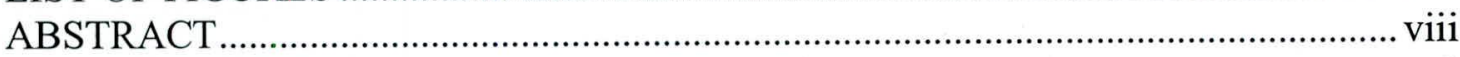

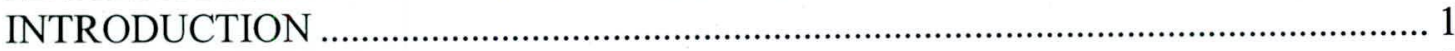

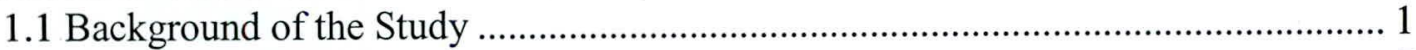

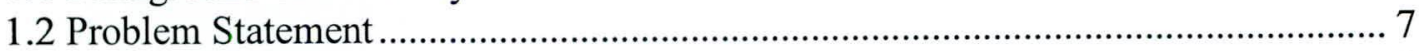

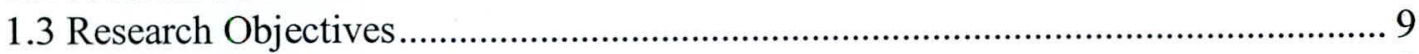

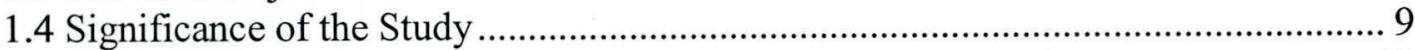

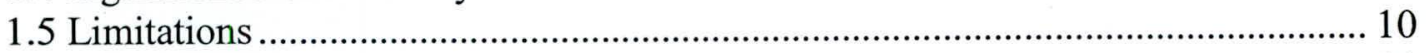

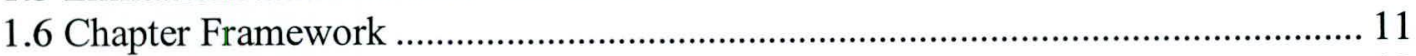

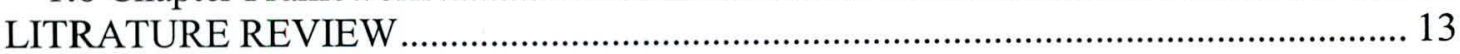

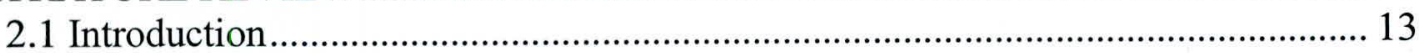

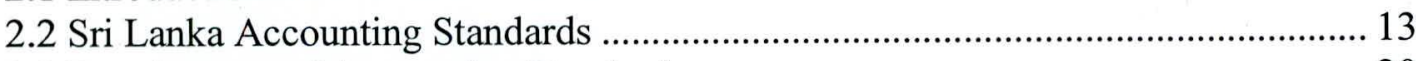

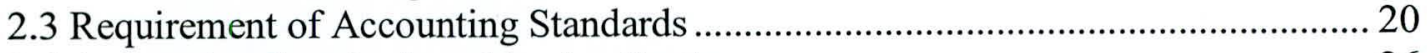

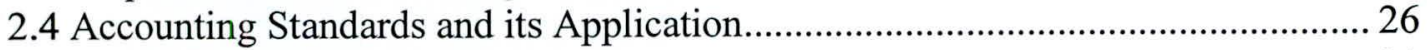

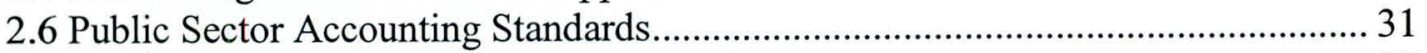

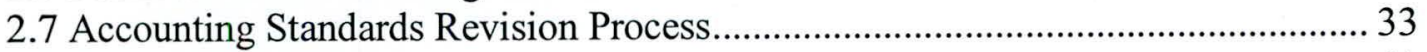

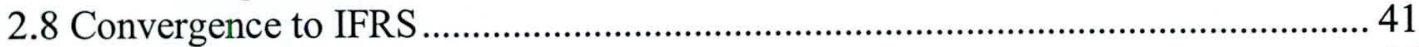

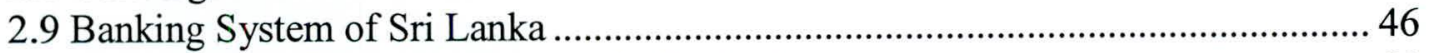

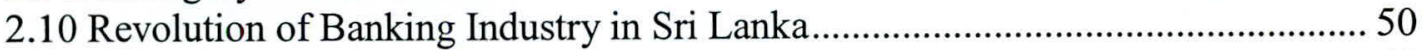

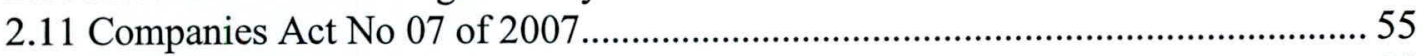

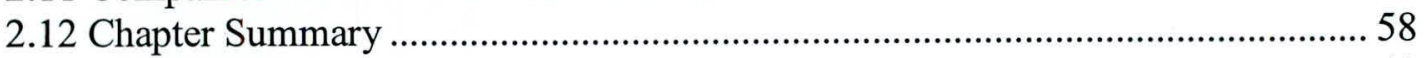

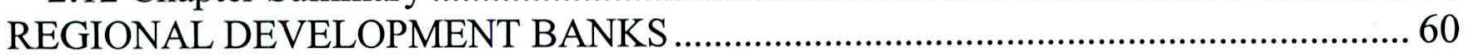

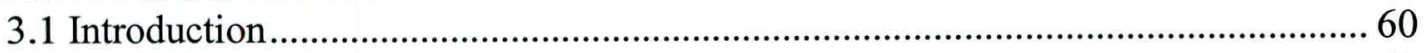

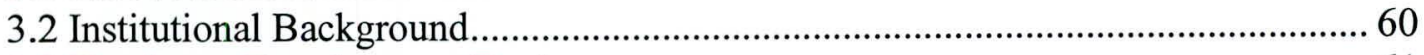

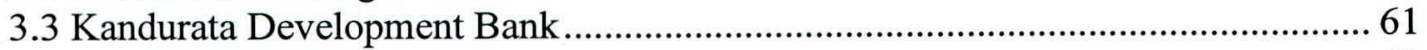

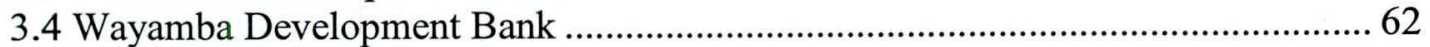

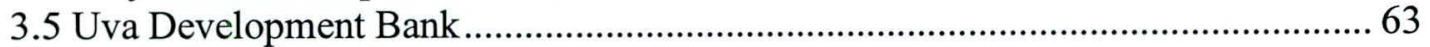

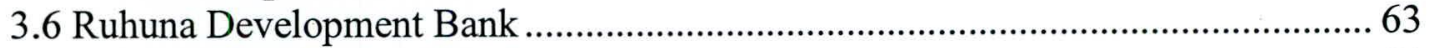

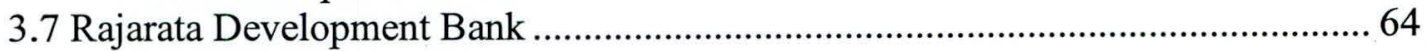

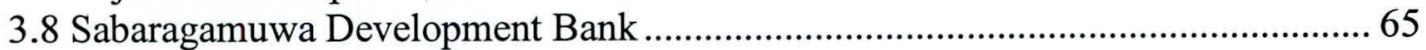

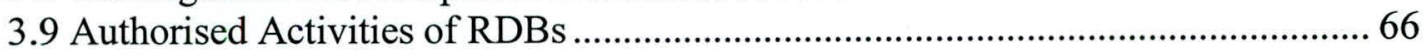

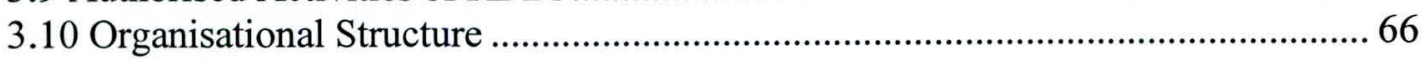

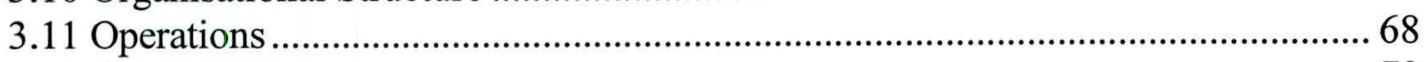

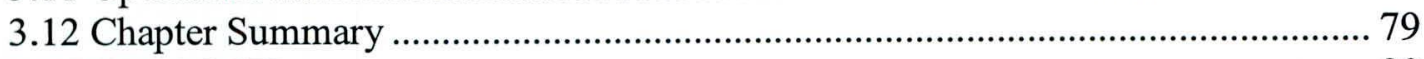

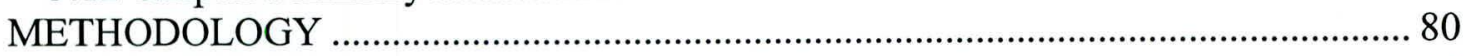

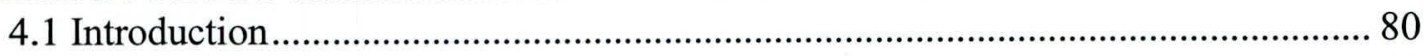

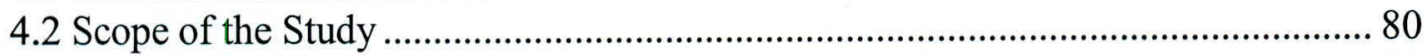

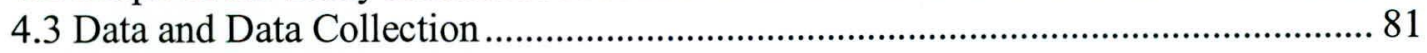

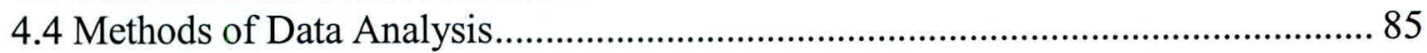

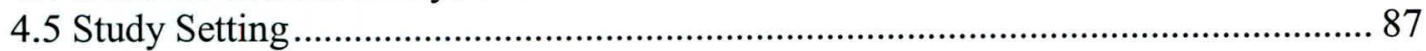

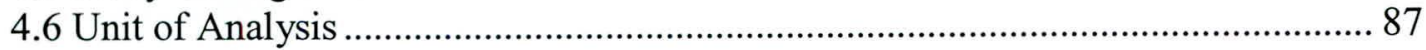




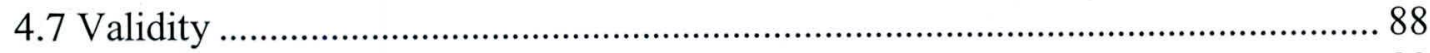

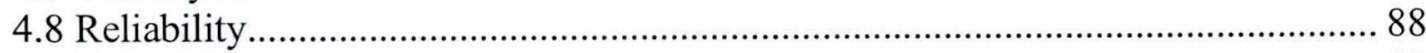

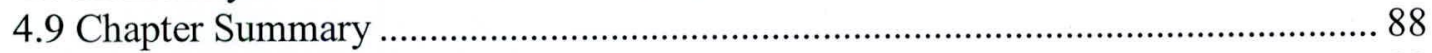

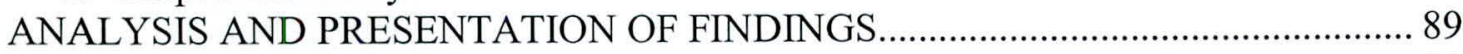

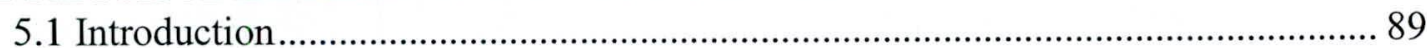

5.2 Compliance with SLAS and Other Regulations by the RDBs.................................. 89

5.3 Deviations from SLAS and Other Regulations by the RDBs .................................. 90

5.4 Overall Summary of Deviations of SLAS and Other Regulations by RDBs ...... 105

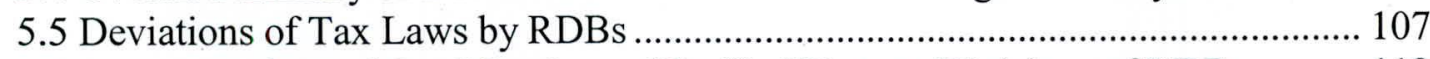

5.6 Competencies and Qualifications of Staff of Finance Divisions of RDBs........... 112

5.7 Educational Qualification of Staff of Finance Divisions of RDBs........................ 114

5.8 Professional Qualifications of Staff of Finance Divisions of RDBs...................... 116

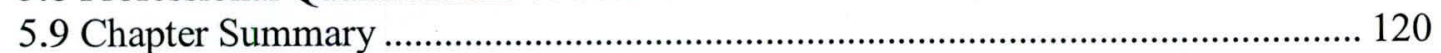

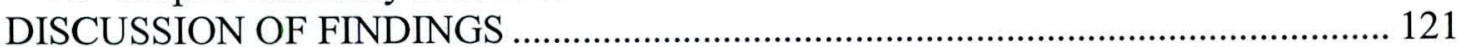

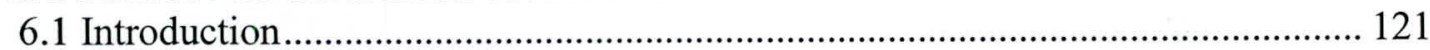

6.2 Difficulties and Complications Faced by the Staff when Applying SLAS .......... 121

6.3 Problems Faced by RDBs when Compared with Other LSBs................................ 123

6.4 Summary of Deviations of SLAS and Other Regulations by RDBs .................... 124

6.5 Recommendation of Mechanism to Overcome the Current Issues Faced by the

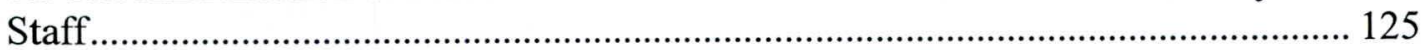

6.6 Issues Recognised in Proposed IFRSs ............................................................... 128

6.7 Chapter Summary ………………………………………………………...... 132

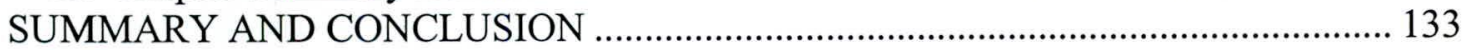

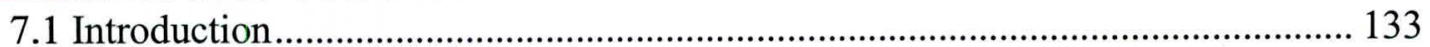

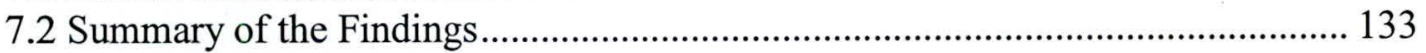

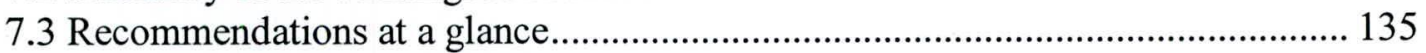

7.4 Recommendations for Future Research ........................................................... 137

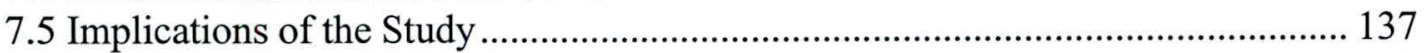

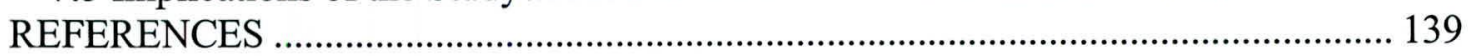

Annexure 1 - Survey Questionnaire........................................................................... 145 


\section{ACKNOWLEDGEMENT}

My grateful thanks to Prof. Samanthi Senarathne, Head, Department of Accountancy, Faculty of Management Studies and Commerce, University of Sri Jayewardenapura for providing me with valuable guidance and advice in carrying out this research successfully. I shall ever remember her kindness and patience, among the burden of her administrational and academic work, for dedicating her valuable time in discussing the research report.

I would also like to extend my gratitude to all the lectures specially for Research Methodology Prof. Henarath H.D.N.P.Opatha, (Professor of Human Resources) and Prof. R.S.Gunathunga, who conducted lectures throughout the two year course of M.Sc. (Management) Programme 2006/ 2007 which helped me to gain the theoretical background of research methodology. Next I pay my gratitude to Dr. P.D.Nimal (Programme Coordinator - M.Sc. Management Programme) for his valuable guidance and encouragement.

I must express my sincere gratitude to all the key officers of six RDBs and the staff members of finance divisions of respective RDBs who completed the questionnaires and returned the same on time enabling me to achieve my target. Further, I must thank the key officers of Bank Supervision Department of CBSL for helping me with providing important information. I also have to specially mention the support given by my superior of Ernst \& Young to complete the study on time.

At last but not least a very special thank to my wife and two kids who were extremely helpful and always provided their fullest support by encouraging me to complete the study by sacrificing their enjoyable time. 


\section{LIST OF ACRONYMS}

\begin{tabular}{ll} 
ADB - & Asian Development Bank \\
AG $\quad-\quad$ & Auditor General \\
CBSL - & Central Bank of Sri Lanka \\
CIGAS- & Computerised Integrated Government Accounting System \\
CSE - & Colombo Stock Exchange \\
DIR - & Department of Inland Revenue \\
FASB - & Financial Accounting Standards Board \\
GAAP - & Generally Accepted Accounting Principles \\
GDP - & Gross Domestic Production \\
IAS - & International Accounting Standards \\
IASB - & International Accounting Standards Board \\
IASC - & International Accounting Standards Committee \\
IBSL - & Insurance Board of Sri Lanka \\
ICAEW & Institute of Chartered Accountants of England and Wales \\
ICASL - & Institute of Chartered Accountants of Sri Lanka \\
IFAC - & International Federation of Accountants \\
IMF - & International Monetary Fund \\
IPSAS - & International Public Sector Accounting Standards \\
KDB - & Kandurata Development Bank \\
LIFO - & Last in First Out method \\
LKR - & Sri Lanka Rupees \\
LSB - & Licensed Specialised Bank \\
\hline
\end{tabular}




\begin{tabular}{|c|c|c|}
\hline NPL & - & Non Performing Loans \\
\hline $\mathrm{PaR}$ & - & Portfolio at Risk \\
\hline $\mathrm{PP} \& \mathrm{E}$ & & Property, Plant and Equipment \\
\hline PSC & - & Public Sector Committee \\
\hline RDB & - & Regional Development Bank \\
\hline $\mathrm{RrDB}$ & - & Rajarata Development Bank \\
\hline RRDB & - & Regional Rural Development Banks \\
\hline RUDB & - & Ruhuna Development Bank \\
\hline SBE & - & Specified Business Enterprises \\
\hline SDB & - & Sabaragamuwa Development Bank \\
\hline SEC & - & Securities and Exchange Commission \\
\hline SLAAS & SMB & Sri Lanka Accounting and Auditing Standards Monitoring Board \\
\hline SLAS & - & Sri Lanka Accounting Standards \\
\hline SME & - & Small and Medium Scale Enterprises \\
\hline UDB & - & Uva Development Bank \\
\hline UK & - & United Kingdom \\
\hline UNDP & - & United Nations Development Programme \\
\hline VAT & - & Value Added Tax \\
\hline WDB & - & Wayamba Development Bank \\
\hline
\end{tabular}




\section{LIST OF TABLES}

Table $1.1 \quad$ - $\quad$ Regional Development Banks in Sri Lanka

Table $1.2 \quad$ - $\quad$ Composition of Licensed Specialised Banks in Sri Lanka 06

$\begin{array}{llll}\text { Table } 2.1 \quad \text { - } & \text { Comparison of SLAS with IAS } & 17\end{array}$

Table $2.2 \quad-\quad$ Membership of Accounting Standards Committee 29

Table 2.3 - Key Changes of Revised SLAS in 2006

$\begin{array}{llll}\text { Table } 3.1 \quad \text { - } & \text { Branch Distribution of RDBs } & 68\end{array}$

Table $3.2 \quad$ - Regional and Sectoral Coverage of RDBs 69

$\begin{array}{llll}\text { Table } 3.3 \quad \text { - } & \text { Products/ Services of RDBs } & 74\end{array}$

$\begin{array}{llll}\text { Table } 3.4 \quad \text { - Staff Competent of RDBs } & 76\end{array}$

Table $3.5 \quad$ - $\quad$ Consolidated Balance Sheet of RDBs as at April 30, 201078

Table $5.1 \quad$ - $\quad$ Non Compliance of SLAS by Individual Banks 91

Table $5.2 \quad-\quad$ Common Non Compliances of SLAS by RDBs 95

Table $5.3 \quad$ - $\quad$ Criteria for Classification of Loans for Provision for

Loan Losses $\quad 100$

Table $5.4 \quad-\quad$ Non Compliance of CBSL Guidelines and the

Provisions of the Companies Act 102

Table 5.5 - $\quad$ Summary of Non Compliances by RDBs 105

Table 5.6 - $\quad$ Awareness of the Staff about Regulatory Requirements 113

Table $5.7 \quad-\quad$ Maximum Educational Qualifications of Finance Staff of $\begin{array}{ll}\text { RDBs } & 115\end{array}$

Table $5.8 \quad-\quad$ Professional Qualifications of Finance Staff of RDBs 116

Table $5.9 \quad-\quad$ Academic and Professional Qualifications against Salaries 117

Table $5.10 \quad-\quad$ Application of Computerised Network Facilities for Banks 119 


\section{LIST OF FIGURES}

Figure $3.1 \quad$ - $\quad$ Economic Activity of RDBs' Clients 71

Figure 5.1 - $\quad$ Awareness of the Staff about Regulatory Requirements 113

Figure 5.2 - $\quad$ Maximum Educational Qualifications of Finance Staff of

$\begin{array}{ll}\text { RDBs } & 115\end{array}$

Figure 5.3 - $\quad$ Professional Qualifications of Finance Staff of RDBs $\quad 116$

Figure $5.4 \quad-\quad$ Academic and Professional Qualifications against Salaries 118

Figure 5.5 - $\quad$ Application of Computerised Network Facilities for Banks 119 


\section{APPLICATION OF SRI LANKA ACCOUNTING STANDARDS AND OTHER REGULATORY REQUIREMENTS BY THE REGIONAL DEVELOPMENT BANKS}

\section{K H R Chandika}

\section{ABSTRACT}

This study examines the compliance of Regional Development Banks (RDB) with Sri Lanka Accounting Standards (SLAS) and the reasons for non-compliances with SLAS. Further, it investigates the compliance of RDBs with other regulatory requirements such as circulars and guidelines issued by the Central Bank of Sri Lanka (CBSL) and the Companies Act No. 07 of 2007. The study was designed to find out the difficulties and complications faced by the staff members of finance divisions of RDBs when applying SLAS and other regulatory requirements. The researcher has carried out a review of annual reports for a period of five years of all six RDBs. This review was supplemented by a questionnaire survey among 46 staff members of finance divisions of all six RDBs. Further, semi structured interviews were carried out with key officers of finance divisions of RDBs to obtain clarifications and explanations regarding the deviations noted, their views and suggestions for the purpose of the study.

The researcher has identified several instances of non-compliances including deviation from SLAS 16 - Employment Benefits, by not obtaining actuarial valuations of gratuity provisions, and failure to make necessary disclosures required by the Sections of SLAS 23.30, SLAS 18.79, SLAS 16.50, SLAS 30.16, 30.17, SLAS 9.42, SLAS 10.14 and SLAS 23.51. Further, the researcher has identified the difficulties faced by the staff of 
RDBs such as lack of technical knowledge about SLAS and absence of proper guidelines and supervision in complying with these requirements. The study recommended a mechanism to overcome the issues recognized during the study. These recommendations include recruiting qualified accountants to the finance divisions, continuous training and development of staff and provision of proper guidelines and supervision of the work of junior officers by responsible officers. 


\section{Chapter 01}

\section{INTRODUCTION}

\subsection{Background of the Study}

The banking sector provides an invaluable service to the economy of any country and directly contributes towards development activities of the society. The banks are playing a vital role in the business environment and customers are expecting the banking system to maintain the confidence by improving the quality and transparency of financial reporting. Financial reporting is one of the most important ways of providing information about the accountability of banks to the owners and the society. Application of SLAS when preparing financial statements will improve the quality of financial information reported by the banks.

Banks represent a significant and influential sector of business all over the world. Most individuals and organizations make use of banks either as borrowers or depositors. Banks play a major role in maintaining confidence in the monetary system through their close relationship with regulatory authorities and the regulations imposed on them by the government. Hence, there is a considerable and widespread interest in the well- being of banks, and in particular, their solvency and liquidity. The operations, and thus the accounting and reporting requirements, of banks are different from those of other commercial enterprises.

Various users of the bank's financial statements are referring to such information for purposes as listed below. 
Users of Financial Statements and their information needs

- Investors - to make investment decisions such as buying and selling of shares and debt equipment of the entities

- Lenders - to ensure the security for their borrowings and entities ability to meet its future obligations

- Employees - to ensure that they are securing their benefits as a return for their efforts towards the growth of the entity and also job security

- Suppliers - to ensure the ability of recovering their dues on time

- Customers - to ensure that the entity's ability to continue for a foreseeable future for them to develop long term relationships

- Government authorities - to ensure proper allocation of resources and to determine taxation policies

- Public - to ensure corporate social responsibilities of the entity towards the society

Therefore, it would be very important to improve the qualitative characteristics of the financial statements to fulfil the common needs of most of the users of such financial information. Further, these statements would be a good indicator to measure the stewardship and accountability of the management towards its ownership. The users of financial statements may compare the financial statements of various business entities with the enhanced qualitative characteristics, more transparent presentation of financial position and performance of the entities which had been prepared by following SLAS. 